\title{
Model Layanan E-Konseling Dengan Media Surat Elektronik Pada Laboratorium Bimbingan Konseling Islam Fakultas Ushuluddin, Adab Dan Dakwah lain Palangka Raya
}

\author{
Arini Safitri \\ Fakultas Ushuluddin, Adab dan Dakwah, Prodi Bimbingan Konseling Islam \\ IAIN Palangka Raya \\ arini.safitri@iain-palangkaraya.ac.id
}

\begin{abstract}
Abstrak
Layanan E-Konseling merupakan salah satu alternatif layanan dalam membantu permasalahan klien yaitu dengan memanfaatkan teknologi, seperti melalui media website, surat elektronik (email), telepon, video, dan jejaring-jejaring sosial lainnya. Teknologi sebagai salah satu media yang dapat memudahkan konselor untuk membantu konselee (klien), yaitu dimana klien dapat dengan lebih leluasa dan nyaman untuk menceritakan semua permasalahannya kepada konselor tanpa harus merasa malu atau takut dihakimi dengan permasalahan yang telah dialami klien. Penelitian ini memiliki tujuan sebagai berikut : (I) Untuk mendeskripsikan administrasi dan prosedur dalam proses e-konseling menggunakan media surat elektronik pada Laboratorium Bimbingan Konseling Islam FUAD IAIN Palangka Raya; (2) Untuk mengetahui keberterimaan pengguna dan ahli Model Layanan E-Konseling Menggunakan Media Surat Elektronik pada Laboratorium Bimbingan Konseling Islam FUAD IAIN Palangka Raya. Penelitian ini menghasilkan buku pedoman layanan e-konseling dengan media surat elektronik pada Laboratorium Bimbingan Konseling Islam FUAD IAIN Palangka Raya, serta model layanan yang berdasarkan aspek kegunaan, kelayakan, ketepatan dan kemungkinan dikerjakannya sudah siap digunakan dengan sedikit perbaikan pengembangan model lebih lanjut sesuai dengan komentar, saran dan perbaikan dari ahli dan praktisi.
\end{abstract}

Kata Kunci: E-Konseling, Surat Elektronik (e-mail)

\begin{abstract}
E-Counseling service is an alternative service in helping client problems, namely by utilizing technology, such as through the media website, electronic mail (e-mail), telephone, video, and other social networks. Technology as one of the media that can make it easier for the counselor to help the counselee (client), which is where the client can more freely and comfortably tell all his problems to the counselor without feeling ashamed or afraid of being judged by the problems the client has experienced. This study has the following objectives: (I) To describe the administration and procedures in the e-counseling process using electronic mail at the Islamic Counseling Guidance Laboratory of FUAD IAIN Palangka Raya; (2) To determine the acceptability of users and experts in the E-Counseling Service Model Using Electronic Mail Media at the Islamic Counseling Guidance Laboratory of FUAD IAIN Palangka Raya. This research produces a guidebook for e-counseling services with electronic mail media at the Islamic Counseling Guidance Laboratory of FUAD IAIN Palangka Raya, as well as a service model based on the aspects of usability, feasibility, accuracy and possibility of doing it ready for use with a slight improvement in further model development according to comments, advice and improvements from experts and practitioners.
\end{abstract}

Keywords : E-Counseling, Electronic Letters (e-mail) 


\section{PENDAHULUAN}

Pengembangan revolusi industri 4.0 dewasa ini merupakan perubahan yang sangat pesat dan cepat, dalam hal salah satunya seperti kegiatan ekonomi yang bersifat agraris akan berubah menjadi kegiatan ekonomi yang bersifat industri, kemudian belum lagi perubahan-perubahan terkait teknologi dan informasi yang nantinya akan berbasis pada mesinmesin berteknologi canggih. Dalam hal ini tentunya seluruh elemen baik dari Sumber Daya Manusia, Sarana dan Prasarana harus siap untuk menghadapi perubahan tersebut. Bimbingan dan Konseling di Perguruan Tinggi sebagai salah satu layanan dalam membantu masalah-masalah yang dihadapi mahasiswa secara khusus dan secara umum seluruh civitas akademika, saat ini kebanyakan masih minim dalam pemanfaatan teknologi pada metode-metode layanan yang digunakan.

Berdasarkan observasi awal pada layanan Bimbingan dan Konseling di IAIN Palangka Raya yaitu pada kegiatan layanan pada Laboratorium Bimbingan dan Konseling Islam FUAD IAIN Palangka Raya secara keseluruhan masih menggunakan metode-metode yang pada umumnya dilakukan pada layanan bimbingan dan konseling di Indonesia yaitu dengan konseling secara langsung/tatap muka (face to face). Tidak dapat dipungkiri bahwa bimbingan dan konseling dengan tatap muka memang tidak bisa tergantikan dengan layanan dalam jarak jauh, dimana pada saat tatap muka seorang konselor maupun konselee (klien) dapat merasakan keterikatan emosional, sehingga munculah rasa empati yang merupakan salah satu syarat yang harus dimiliki oleh seorang konselor dalam membantu masalah konselee. Akan tetapi, dengan melihat presentase sasaran penggunaan layanan bimbingan dan konseling di Perguruan Tinggi khususnya IAIN Palangka Raya ialah mahasiswa yang kebanyakan remaja dan termasuk dalam generasi $Y$ atau generasi milenial, yang sangat mengikuti dan memanfaatkan perkembangan teknologi dengan cepat. Berdasarkan data Badan Pusat Statistik dalam Profil Generasi Milenial Indonesia (2018) generasi milenial memiliki persentase tertinggi dibandingkan dengan generasi sebelumnya dalam pemanfaatan teknologi seperti penggunaan Telepon Seluler (HP) yaitu sudah mencapai 91,62\% yang mana persentase ini lebih tinggi daripada generasi $X$ yang sebesar $77,02 \%$ dan generasi baby boom dan veteran yang hanya memiliki persentase $43,72 \%$. Sedangkan untuk penggunaan komputer (PC/laptop/notebook/tablet, dII) generasi milenial juga lebih unggul dibandingkan generasi sebelumnya yaitu dengan persentase sebesar 29,57\%, kemudian disusul dengan penggunaan internet yang mana berdasarkan data dari tahun ke tahun generasi milenial mengalami peningkatan dalam mengakses internet pada Tahun 2015 sebesar 40,78\%, Tahun 2016 sebesar 46,29\%, dan pada Tahun 2017 sebesar 56,42\%. Hal ini senada dengan hasil penelitian yang dilakukan (Deal et al., 20I0) dan (Blackburn, 20I I) tentang generasi milenial yang menyatakan bahwa generasi ini lebih unggul dalam pemanfaatan teknologi dibandingkan dengan generasi sebelumnya. Maka dari itu, untuk tetap menjaga eksistensi penggunaan layanan bimbingan dan konseling, perlu adanya program layanan yang berbasis teknologi.

Layanan E-Konseling merupakan salah satu alternatif layanan dalam membantu permasalahan klien yaitu dengan memanfaatkan teknologi, seperti melalui media website, surat elektronik (email), telepon, video, dan jejaring-jejaring sosial lainnya. Teknologi sebagai salah satu media yang dapat memudahkan konselor untuk membantu konselee (klien), yaitu dimana klien dapat dengan lebih leluasa dan nyaman untuk menceritakan semua 
permasalahannya kepada konselor tanpa harus merasa malu atau takut dihakimi dengan permasalahan yang telah dialami klien. Penggunaan teknologi dalam proses konseling juga dapat memberikan suatu pengaruh yang sangat besar, dikarenakan banyaknya orang yang menjadikan teknologi seperti internet sebagai suatu kebutuhan karena dapat membantu dengan cepat segala yang diinginkan oleh penggunanya, sehingga besar harapan layanan e-konseling dapat pula menjadi suatu kebutuhan untuk dimanfaatkan pada saat seseorang sedang menghadapi suatu permasalahan dalam berbagai aspek kehidupannya.

Surat elektronik (email) sebagai aplikasi utama pada jaringan di internet menjadikan email dapat menjadi salah satu media yang cukup efektif dalam menunjang layanan e-konseling, dikarenakan kebanyakan orang pasti memiliki email terutama kalangan remaja yang memiliki social media yang registrasi dan aktivasinya menggunakan email. Pengamanan kerahasiaan email pada saat ini semakin menuju ke arah yang semakin baik dan terjaga keamanannya, seperti adanya kode verifikasi atau notifikasi yang dikirimkan ke nomor ponsel atau email pemulihan apabila ada orang lain log in email melalui perangkat yang baru, tidak dikenal, dan dideteksi berbahaya. Hal ini dapat menjadi salah satu faktor pendukung kenyamanan klien untuk menceritakan permasalahannya tanpa harus bertatap muka.

\section{METODE PENELITIAN}

Metode yang digunakan pada penelitian ini adalah metode research \& development. Penggunaan metode research \& development berdasarkan pada pertimbangan bahwa metode ini efektif untuk mengembangkan maupun menghasilkan produkproduk pada bidang pendidikan (Sugiyono, 2018).
Research \& development adalah suatu proses pengembangan suatu produk baru atau penyempurnaan produk yang telah ada dan sehingga dapat untuk dipertanggungjawabkan. Produk dalam research \& development dapat berupa perangkat keras ataupun perangkat lunak. Perangkat keras misalnya seperti buku, modul, alat bantu untuk pembelajaran pada bidang Pendidikan atau di laboratorium. Perangkat lunak meliputi program komputer dalam pengolahan data, pembelajaran, perpustakaan atau laboratorium, serta model-model pendidikan, pembelajaran, pelatihan, bimbingan, evaluasi, manajemen, dan lain-lain.

Langkah-langkah dalam research \& development yang akan dilakukan terdiri dari 7 tahapan yaitu : (I) Potensi dan Masalah; (2) Mengumpulkan Informasi; (3) Desain produk; (4) Validasi Desain; (5) Perbaikan Desain; (6) Pembuatan Produk; dan (7) Uji Coba Produk. Desain produk dalam research \& development ini adalah Model Layanan E-Konseling Menggunakan Media Surat Elektronik. Validasi desain produk akan dilakukan dengan uji ahli oleh seorang Dosen BK dan Dosen TI, sedangkan uji pengguna akan dilakukan oleh dua orang konselor Laboratorium Bimbingan Konseling Islam FUAD IAIN Palangka Raya. Uji ahli dan pengguna dilakukan untuk memvalidasi model hipotetik menjadi model rasional.

Desain validasi dan uji penggunaan model dalam research and development meliputi tahap penilaian yang dilakukan oleh 1 orang ahli 2 orang Konselor/Psikolog/praktisi untuk uji model ekonseling dengan media surat elektronik pada Laboratorium Bimbingan Konseling Islam. Setelah model direvisi, dilakukan uji penggunaan model oleh mahasiswa. Uji penggunaan model oleh mahasiswa dilakukan sebanyak dua kali, yaitu dalam uji coba 
terbatas yang terdiri dari mahasiswa Program Studi Bimbingan Konseling Islam angkatan 2018 sebanyak 8 orang dan uji coba pemakaian dengan subjek mahasiswa Program Studi Bimbingan Konseling Islam angkatan 2017, 2019, dan 2020 sebanyak 35 orang. Berdasarkan hasil uji coba terbatas tersebut, produk direvisi. Hasil revisi produk dalam uji coba terbatas, digunakan dalam uji coba pemakaian. Berdasarkan hasil uji coba pemakaian, maka selanjutnya model direvisi sehingga menghasilkan model akhir yaitu model e-konseling dengan media surat elektronik pada Laboratorium Bimbingan Konseling Islam.

Validator dalam penelitian ini adalah ahli dalam bimbingan dan konseling yaitu Dosen Bimbingan dan Konseling di Perguruan Tinggi Negeri Kota Palangka Raya dengan latar belakang Pendidikan Magister Bimbingan dan Konseling dan Profesi Psikologi. Sedangkan subjek untuk uji penggunaan adalah sebagai mahasiswa Program Studi Bimbingan Konseling Islam, sehingga sangat familiar dengan layanan konseling dalam merespon penggunaan model e-konseling dengan media surat elektronik pada Laboratorium Bimbingan Konseling Islam.

Data yang didapatkan dalam research \& development terdiri dari dua macam yaitu yang pertama data proses pengembangan model ekonseling dengan media surat elektronik pada Laboratorium Bimbingan Konseling Islam sesuai dengan masukan dari para ahli dan kriteria yang telah ditentukan, dan yang kedua ialah data tentang kebertimaan/akseptabilitas model e-konseling dengan media surat elektronik pada Laboratorium Bimbingan Konseling Islam sesuai dengan hasil uji coba terbatas dan uji pemakaian.
Pada penelitian ini instrumen yang digunakan adalah lembar penilaian akseptabilitas/keberterimaan untuk validator ahli dan praktisi terhadap model layanan ekonseling dengan media surat elektronik pada Laboratorium Bimbingan Konseling Islam, serta lembar penilaian pelaksanaan dan hasil layanan ekonseling dengan media surat elektronik pada Laboratorium Bimbingan Konseling Islam untuk uji penggunaan oleh mahasiswa. Instrumen penilaian akseptabilitas/keberterimaan untuk validator ahli dan praktisi serta instrumen penilaian pelaksanaan dan hasil mengacu pada aspek-aspek tentang kriteria akseptabilitas, evaluasi pelaksanaan dan hasil oleh The Joint Committee On Standards For Educational Evaluation (Stufflebeam, 1994). Kisi-kisi instrumen penilaian akseptabilitas/keberterimaan untuk validator ahli dan praktisi terhadap model layanan ekonseling dengan media surat elektronik pada Laboratorium Bimbingan Konseling Islam adalah sebagai berikut :

Tabel I. Kisi-kisi Instrumen Penilaian Akseptabilitas/Keberterimaan Validator Ahli dan Praktisi

\begin{tabular}{clc}
\hline No & \multicolumn{1}{c}{ Aspek yang Dinilai } \\
\hline I & $\begin{array}{l}\text { Kontribusi model terhadap } \\
\text { pencapaian tujuan } \\
\text { bimbingan konseling }\end{array}$ \\
\hline 2 & Peluang keterlaksanaan \\
\hline 3 & $\begin{array}{l}\text { Kemampuan } \\
\text { menerapkan model }\end{array}$ \\
\hline 4 & $\begin{array}{l}\text { Kesesuaian model } \\
\text { karakteristik konseli }\end{array}$ \\
\hline 5 & Model mudah di pahami \\
\hline 6 & $\begin{array}{l}\text { Tahap-tahap dalam pelaksanaan } \\
\text { model layanan e-konseling dengan } \\
\text { media surat elektronik (tahap }\end{array}$ \\
& $\begin{array}{l}\text { pembukaan, peralihan, kegiatan, } \\
\text { dan pengakhiran) sesuai dengan } \\
\text { tujuan yang ingin di capai. }\end{array}$ \\
\hline 7 & $\begin{array}{l}\text { Peluang keterjalinan proses } \\
\text { terapetik pada konseli melalui } \\
\text { tulisan email. }\end{array}$ \\
\hline 8 & $\begin{array}{l}\text { Panduan Pelaksanaan model } \\
\text { layanan e-konseling dengan media }\end{array}$ \\
\hline &
\end{tabular}


surat elektronik (Kejelasan kalimat dan kesesuaian pelaksanaan layanan yang dikembangkan dengan tujuan, asumsi, target intervensi, dan komponen model)

Tabel 2. Kisi-kisi Instrumen Penilaian Pelaksanaan Layanan EKonseling dengan Media Surat Elektronik

\begin{tabular}{ll}
\hline No & \multicolumn{1}{c}{ Aspek yang dinilai } \\
\hline I & Teknik yang digunakan \\
\hline 2 & $\begin{array}{l}\text { Tahap Awal atau pendahuluan } \\
\text { layanan e-konseling }\end{array}$ \\
\hline 3 & Tahap inti \\
\hline 4 & Tahap penutup \\
\hline 5 & Materi Layanan \\
\hline 6 & Metode Layanan \\
\hline 7 & $\begin{array}{l}\text { Hambatan yang dialami selama } \\
\text { kegiatan }\end{array}$ \\
\hline
\end{tabular}

Tabel 3. Kisi-kisi Instrumen Penilaian Hasil Layanan E-Konseling dengan Media Surat Elektronik

\begin{tabular}{cll}
\hline No & \multicolumn{3}{c}{ Aspek yang dinilai } \\
\hline I & $\begin{array}{l}\text { Suasana yang dirasakan klien } \\
\text { selama pelaksanaan layanan }\end{array}$ \\
\hline 2 & $\begin{array}{l}\text { Pemahaman klien terhadap } \\
\text { pelaksanaan layanan }\end{array}$ \\
\hline 3 & $\begin{array}{l}\text { Perubahan perilaku yang terjadi } \\
\text { pada klien setelah layanan }\end{array}$ \\
\hline 4 & $\begin{array}{l}\text { Teratasinya permasalahan yang } \\
\text { dialami klien }\end{array}$ \\
\hline & Instrumen
\end{tabular}

akseptabilitas/keberterimaan untuk validator ahli dan praktisi serta instrumen penilaian pelaksanaan dan hasil mengacu pada aspek-aspek tentang kriteria akseptabilitas, evaluasi pelaksanaan dan hasil menggunakan skala penilaian angka I -4, dengan gradasi skala penilaian 4 (sangat baik/sangat tepat/sangat sesuai), angka 3
(Baik/tepat/sesuai), angka 2 (kurang baik/kurang tepat/kurang sesuai), dan angka I (tidak baik/tidak tepat/tidak sesuai).

Teknik analisis data yang digunakan dalam penelitian ini adalah analisis deskriptif, dengan beberapa langkah yaitu dengan melihat skor kuantitatif yang kemudian dideskripsikan menjadi kualitatif berdasarkan pada kriteria penilaian sebagai berikut:

Tabel 4. Kriteria Penilaian Instrumen Akseptabilitas/Keberterimaan Validator Ahli dan Praktisi

\begin{tabular}{ccc}
\hline $\begin{array}{c}\text { Rentang } \\
\text { Skor }\end{array}$ & Nilai & Simpulan \\
\hline 26 s/d 32 & Sangat & Model ini sudah \\
& $\begin{array}{c}\text { tepat/sangat } \\
\text { tepat/sangat } \\
\text { sesuai }\end{array}$ & $\begin{array}{c}\text { siap digunakan } \\
\text { dengan sedikit } \\
\text { perbaikan saran }\end{array}$ \\
\hline 20 s/d 26 & Baik/tepat/sesuai & Model ini \\
& & membutuhkan \\
& & beberapa \\
& & $\begin{array}{c}\text { perbaikan } \\
\text { sebelum } \\
\text { digunakan. }\end{array}$ \\
\hline I4 s/d 20 & Kurang & $\begin{array}{c}\text { Model ini } \\
\text { membutuhkan }\end{array}$ \\
& baik/kurang & tepat/kurang \\
& sesuai & banyak perbaikan \\
& & sebelum \\
& digunakan. \\
\hline 8 s/d I4 & Tidak baik/tidak & Model ini belum \\
& tepat/tidak & dapat digunakan \\
& sesuai & dan membutuhkan \\
& banyak perbaikan. \\
\hline
\end{tabular}

Tabel 5. Kriteria Instrumen Penilaian Pelaksanaan Layanan E-Konseling dengan Surat Elektronik pada Laboratorium Bimbingan Konseling Islam

\begin{tabular}{ccc}
\hline $\begin{array}{c}\text { Rentang } \\
\text { Skor }\end{array}$ & Nilai & Simpulan \\
\hline $75-100$ & Baik & $\begin{array}{c}\text { Proses pelaksanaan } \\
\text { model layanan } \\
\end{array}$ \\
& & sudah siap untuk \\
& diaplikasikan \\
& dengan sedikit \\
& perbaikan saran. \\
\hline
\end{tabular}




\begin{tabular}{|c|c|c|}
\hline $50-74$ & Cukup & $\begin{array}{l}\text { Proses pelaksanaan } \\
\text { model layanan } \\
\text { masih } \\
\text { membutuhkan } \\
\text { beberapa perbaikan } \\
\text { sebelum } \\
\text { diaplikasikan }\end{array}$ \\
\hline $25-49$ & Kurang & $\begin{array}{c}\text { Proses pelaksanaan } \\
\text { model layanan } \\
\text { belum dapat } \\
\text { digunakan } \\
\text { dikarenakan } \\
\text { membutuhkan } \\
\text { banyak perbaikan. }\end{array}$ \\
\hline
\end{tabular}

Pengembangan model layanan e-konseling di Laboratorium Bimbingan Konseling Islam FUAD IAIN Palangka Raya dilakukan dengan beberapa tahapan, yaitu sebagai berikut:

Pada tahapan analisis ini dilakukan analisis kebutuhan di lapangan dan pengguna layanan/klien/mahasiswa Laboratorium Bimbingan Konseling Islam yang berupa hambatan-hambatan serta peluang-peluang yang dapat memberikan informasi maupun data dalam pengembangan model layanan konseling yang efektif dan efisien di

\section{Tabel 6. Kriteria Instrumen Penilaian Hasil Layanan E-Konseling dengan Surat Elektronik pada Laboratorium Bimbingan Konseling Islam}

\begin{tabular}{|c|c|c|}
\hline $\begin{array}{c}\text { Kriteria } \\
\text { Jawaban }\end{array}$ & Nilai & Simpulan \\
\hline $\begin{array}{c}\text { Sangat } \\
\text { Baik/Sangat } \\
\text { Paham/Sangat } \\
\text { Teratasi }\end{array}$ & 4 & $\begin{array}{c}\text { Model ini sudah siap } \\
\text { digunakan dengan } \\
\text { sedikit perbaikan } \\
\text { saran }\end{array}$ \\
\hline $\begin{array}{c}\text { Baik/Paham/Ter } \\
\text { atasi }\end{array}$ & 3 & $\begin{array}{c}\text { Model ini } \\
\text { membutuhkan } \\
\text { beberapa perbaikan } \\
\text { sebelum digunakan. }\end{array}$ \\
\hline $\begin{array}{c}\text { Cukup } \\
\text { Baik/Cukup } \\
\text { Paham/Cukup } \\
\text { Teratasi } \\
\end{array}$ & 2 & $\begin{array}{c}\text { Model ini } \\
\text { membutuhkan } \\
\text { banyak perbaikan } \\
\text { sebelum digunakan. }\end{array}$ \\
\hline $\begin{array}{c}\text { Kurang } \\
\text { Baik/Kurang } \\
\text { Paham/Kurang } \\
\text { Teratasi } \\
\end{array}$ & 1 & $\begin{array}{c}\text { Model ini belum } \\
\text { dapat digunakan dan } \\
\text { membutuhkan } \\
\text { banyak perbaikan. }\end{array}$ \\
\hline
\end{tabular}

Pengembangan layanan konseling di Laboratorium Bimbingan Konseling Islam FUAD IAIN Palangka Raya menghasilkan produk/model layanan berbasis elektronik (e-konseling) dengan surat elektronik (email). Model layanan e-konseling dibuat pada halaman website resmi Program Studi BKI dengan alamat web sebagai berikut http://bki.fuad.iain-palangkaraya.ac.id/ yaitu pada menu e-form yang dapat diakses oleh semua mahasiswa khususnya di IAIN Palangka Raya.
Laboratorium Bimbingan Konseling Islam. Pengumpulan informasi dan data dilakukan dengan metode wawancara dan observasi. Hasil wawancara yang didapatkan yaitu kurangnya keinginan mahasiswa untuk datang langsung ke Laboratorium Bimbingan Konseling Islam dengan berbagai alasan, salah satunya yaitu merasa malu untuk secara langsung mengungkapkan permasalahannya. Selanjutnya pada proses wawancara dengan pengguna langsung layanan konseling di Laboratorium Bimbingan Konseling Islam menyatakan bahwa kurang efektifnya waktu apabila harus dating ke Laboratorium Bimbingan Konseling Islam pada saat harus berbagi waktu dengan padatnya jadwal perkuliahan. Sedangkan hasil dari observasi langsung peneliti ke lapangan, terlihat bahwa memang petugas/konselor di Laboratorium Bimbingan Konseling Islam tidak bias selalu standby di tempat, mengingat profesi konselor yang juga sebagai tenaga pengajar di IAIN Palangka Raya, selain itu Laboratorium Bimbingan Konseling Islam juga belum mempunyai staf khusus/bagian administrasi dalam pelayanan konseling.

\section{HASIL PENELITIAN DAN PEMBAHASAN}

Berdasarkan uji ahli dan praktisi terhadap kegunaan, kelayakan, ketepatan dan kemungkinan 
dikerjakannya layanan e-konseling dengan media surat elektronik di Laboratorium Bimbingan Konseling Islam didapatkan hasil rata-rata skor 26 yaitu termasuk dalam kategori sangat tepat/sangat baik/sangat sesuai yang artinya model layanan ekonseling melalui media surat elektronik di Laboratorium Bimbingan Konseling Islam sudah siap digunakan dengan sedikit perbaikan pengembangan model lebih lanjut sesuai dengan komentar, saran dan perbaikan dari ahli dan praktisi. Hal ini sesuai dengan pendapat Baugus, 200 I (dalam Pedhu, 20I4) yang menyatakan bahwa penggunaan media surat elektronik (e-mail) dalam layanan konseling merupakan cara yang pada umumnya dan efektif digunakan konselor untuk berinteraksi dengan klien dalam konseling online. Sussman (dalam Pedhu, 20I4) juga memaparkan bahwa e-mail ialah salah satu cara yang paling mudah bagi konselor untuk membangun komunikasi online dengan klien. E-mail merupakan suatu bentuk komunikasi yang tersedia dan mudah antara individu-individu yang berdekatan dan juga dengan individu-individu di seluruh dunia yang berjauhan.

Selanjutnya berdasarkan uji penggunaan terhadap proses dan hasil pelaksanaan model layanan e-konseling melalui media surat elektronik di Laboratorium Bimbingan Konseling Islam didapatkan hasil pada kategori Baik/Paham/Teratasi. Hal ini sejalan dengan pendapat (Murphy \& Mitchell, 1998) bahwa kelebihan - kelebihan yang terdapat pada konseling online/konseling elektronik dengan e-mail dapat memberikan pemaknaan positif pada klien selama proses konseling maupun hasil yang dirasakan setelah konseling selesai, seperti tersimpannya script atau catatan selama proses konseling yang dapat digunakan sebagai data primer bagi konselor dan bagi klien menjadi catatan yang selalu dapat dibaca berulang-ulang, dan proses pada saat klien mengetik atau menuliskan teks pada surat elektronik merupakan sarana dalam mencurahkan dan merefleksikan permasalahannya, sehingga klien dapat menuliskan pesan pada surat elektronik kapanpun yang ia inginkan, terutama pada saat berada ditengah permasalahan tanpa harus menunggu bertemu dengan konselor ((Pedhu, 2014).

\section{KESIMPULAN}

Berdasarkan uji ahli dan praktisi yang telah dipaparkan sebelumnya, peneliti menyimpulkan model layanan e-konseling melalui media surat elektronik di Laboratorium Bimbingan Konseling Islam sudah siap di gunakan, layakan, dan tepat layanan e-konseling dengan media surat elektronik di Laboratorium Bimbingan Konseling Islam. Penggunaan media surat elektronik (e-mail) dalam layanan konseling merupakan cara yang pada umumnya dan efektif digunakan konselor untuk berinteraksi dengan klien dalam konseling online. $E$ mail merupakan suatu bentuk komunikasi yang tersedia dan mudah antara individu-individu yang berdekatan dan juga dengan individu-individu di seluruh dunia yang berjauhan.

\section{REFERENSI}

Blackburn, H. (20I I). Millennials and the adoption of new technologies in libraries through the diffusion of innovations process. Library $\mathrm{Hi}$ Tech. https://doi.org/10.1 108/0737883 I I I I I89769

Deal, J. J., Altman, D. G., \& Rogelberg, S. G. (20I0). Millennials at work: What we know and what we need to do (if anything). Journal of Business and Psychology. https://doi.org// 0.1007/s 10869-010-9177-2

Murphy, L. J., \& Mitchell, D. L. (1998). When writing helps to heal: E-mail as therapy. British Journal of Guidance and Counselling. 
https://doi.org// 0.1080/03069889808253835

Pedhu, Y. (20/4). Model Konseptual Cybercounseling Berbasis E-Mail. Jurnal Psiko Edukasi.

Stufflebeam, D. L. (1994). Empowerment Evaluation, Objectivist Evaluation, and Evaluation Standards: Where the Future of Evaluation Should Not Go and Where It Needs to Go. American Journal of Evaluation. https://doi.org/ I 0.1 I 77//10982 | 40940 I5003 I

3

Sugiyono. (2018). Metode Penelitian Kuantitatif,Kualitatif dan R\&D. In ke-26. 